Full-text Available Online at www.ajol.info and www.bioline.org.br/ja
J. Appl. Sci. Environ. Manage. December, 2014

Vol. 18 (4) 623-627

\title{
Resistance to some Heavy Metals among Fungal Flora of Raw Refinery Effluent
}

\author{
*11EZEONUEGBU, B.A.; MACHIDO, D.A.; YAKUBU, S.E
}

\author{
Department of Microbiology, Ahmadu Bello University Zaria, Kaduna State
}

*Corresponding Author: amakaezeonu@gmail.com

KEY WORDS: Fungal flora, Heavy metals, Resistance, Refinery effluents

\begin{abstract}
Investigations were carried out to assess the capacity of strains of fungi isolated from raw flowing effluent and effluent retention pond of Kaduna refinery plant to resist and grow in the presence of lead $(\mathrm{Pb})$, nickel $(\mathrm{Ni})$ and cadmium $(\mathrm{Cd})$ invitro. Fungi belonging to the genera including Aspergillus spp., Penicillium spp., Fusarium spp., Curvularia spp. and Nigrospora spp. were isolated from the study sites. The isolates were inoculated into duplicate $100 \mathrm{ml}$ flask containing $50 \mathrm{ml}$ of potato dextrose broth (PDB) supplemented with 5,10 and $15 \mathrm{ppm}$ of $\mathrm{Pb}, \mathrm{Ni}$, and $\mathrm{Cd}$. Each test isolate was inoculated into duplicate flask containing the same medium without the heavy metals to serve as control. All inoculated flasks were incubated aerobically at room temperature on a rotator shaker for 7days. The mycelial mats were harvested by filtering the cultures through preweighed filter paper (No.1). The filters bearing the mycelial mats were dried in an oven at $70^{\circ} \mathrm{C}$ for 18 hours. It was observed that most of the isolates tested resisted and grew in the medium containing 5 to $15 \mathrm{ppm}$ of tested heavy metals. Yield of dry mycelia mats in the heavy metal supplemented medium were also comparable to those grown in heavy metal free PDB medium. It was concluded that, these genera of fungi could be playing an important role in the removal of these metals usually present in the raw effluent during the period of residency in the retention pond through bioaccumulation. @JASEM
\end{abstract}

http://dx.doi.org/10.4314/jasem.v18i4.10

\section{Introduction}

The survival of a fungus in raw untreated effluents from petroleum refining, effluent retention pond and water bodies impacted by the effluent would require that ; (i) it will be able to grow at the expense of hydrocarbons (HCs) as the main source of carbon and energy (Cerrniglia et al., 1992; Ulfig et al., 2003). (ii) It withstands the toxicity of a wide range of polycyclic aromatic hydrocarbons (PAHs) that are components of untreated effluents (Kari et al., 2003, Bako et al., 2008). (iii) Will be able to resist and grow in the presence of high levels of toxic heavy metal ions typical of all petroleum refinery effluents (Van Hamme et al., 2003; Ayenimo et al., 2005, Emoyan et al., 2006; Dugal and Gangawane, 2012).

Several reports on the preponderance of fungi in petroleum refinery effluents and sites impacted by effluents (Barrat et al., 2001; Ulfig et al., 2003; Urooj et al., 2013), suggest that, the genera and species detected possess mechanisms by which these ecological challenges are circumvented. Production and secretion of wide range of extracellular enzymes by fungi enable them to exploit a great variety of HCs including the toxic PAHs (Ulfig et al., 2003;
Kari et al., 2003). In the process, the mycoflora in the effluent retention ponds play a role in the biodegradation of the HCs components of raw effluents. This contributes significantly in improving the effluent quality at the point of discharge into the environment.

Often however, high levels of toxic heavy metal ions remain a major challenge to the survival and growth of fungi, even after the toxic HCs and PAHs have been detoxified. Several mechanisms have been reported by which fungi as a group circumvent the threat to their survival in environments impacted by heavy metal rich refinery effluents. Among them, bioconversion (David and Jay, 2009), bioadsorption (Shankar et al., 2007; Nilanjana et al., 2008; Ashok et al., 2010) and bioaccumulation (David and Jay, 2009; Martin et al., 2010) are considered as the main mechanisms by which fungi are able to remove toxic heavy ions from their growth environment. This special attributes of fungi are already being tested towards identifying and selecting genera and species that could be employed as agent of mycoremediation of toxic heavy metal rich effluents and heavy metal polluted sites (Nilanjana et al., 2006; Wuyep et al., 
2007; Ashok et al., 2010). This paper is a report of investigations conducted to assess the resistance of four species of Aspergillus and four other genera isolated from untreated refinery effluents, waste retention pond of Kaduna refinery and petrochemical company (KRPC) and the river receiving the partially treated effluents.

\section{MATERIALS AND METHODS}

Sample collection: Effluent from Kaduna Refinery and petrochemical company (KRPC) and water sample from Romi River were collected in sterile bottles from five sites namely; untreated waste water channel (site A), Waste oil retention pond (site B), Discharge point (site C), upstream of Romi River (site D) and downstream of Romi River (site E). All sample bottles containing the $100 \mathrm{ml}$ of the samples in duplicate were properly labeled before transporting them in ice box to the laboratory. All samples were analyzed without delay in order to avoid microbial deterioration of the samples.

Isolation of fungal Flora: The sample containers were set and allowed to stand at room temperature on a thoroughly disinfected laboratory work bench for 30 minutes to concentrate the sample by sedimentation. The supernatants were decanted to about $50 \mathrm{ml}$ volume followed by rigorous shaking to resuspend the sediments. Ten (10) militers of each sample were placed in duplicate sterile centrifuge tubes and spinned at $250 \mathrm{rpm}$ for 10 minutes to further concentrate the fungal propagules present in the samples. $0.1 \mathrm{ml}$ aliquot of the suspensions were spread inoculated on duplicate plates of freshly prepared potato carrot agar (PCA) and potato dextrose agar with $7.5 \% \mathrm{Nacl}$ supplemented with $50 \mu \mathrm{g} / \mathrm{l}$ of chloramphenicol to suppress bacterial growth using sterile bent glass rod. All inoculated plates were incubated aerobically at room temperature $\left(30^{\circ} \mathrm{C}\right)$ in disinfected dark cupboard for 7 days.

Identification of fungal isolates: All the fungal isolates obtained from the various samples analyzed were identified based on their micromorphological characteristics. Criteria such as presence or absence of septation, presence of foot cell at the base of conidiophores, chlamydospores, and structures of asexual fruiting bodies, production of micro and / or macroconidia were used to identify the isolates to generic levels with reference to appropriate taxonomic guides (Klich, 2002; Nagamani et al., 2006; Hakeem and Bhatnagar, 2010; Thippaswamy et al.,2012). Eight (8) fungal isolates; Aspergillus niger, Aspergillus flavus, Aspergillus fumigatus, Aspergillus carbonarius, Penicillum sp., Fusarium, Curvularia sp. and Nigrospora sp. were identified.

Preparation of Stock Solutions of Heavy Metal Ions: Stock solutions of lead nitrate $\left(\mathrm{Pb}\left(\mathrm{NO}_{3}\right)_{2}\right)$, nickel sulphate $\left(\mathrm{NiSO}_{4}\right)$ and cadmium sulphate were prepared by dissolving $0.1 \mathrm{~g}$ of each salt in separate conical flasks containing $500 \mathrm{ml}$ of distilled water. The flasks were warmed over hot plate with vigorous shaking to obtain a clear solution of to obtain 200 $\mu \mathrm{g} / \mathrm{ml}$ concentrations. The solutions were stored in a refrigerator at $4^{\circ} \mathrm{C}$ for later use.

Bioassay Procedure: The fungal isolates were bioassayed for their capacity to resist and grow in the presence of 5,10 and $15 \mu \mathrm{g} / \mathrm{ml}$ of the test heavy metal ions invitro. The yields of biomass in liquid shake cultures were used as index of resistance and growth in the presence of experimental concentrations of the heavy metals. (Bennet et al., 1997).

Each test isolates were inoculated in duplicate conical flasks containing $100 \mathrm{ml}$ of freshly prepared potato carrot broth supplemented with 5, 10 and $15 \mu \mathrm{g} / \mathrm{ml}$ of $\mathrm{Pb}, \mathrm{Ni}$, and $\mathrm{Cd}$. The inoculated flasks were incubated at room temperature $\left(30^{\circ} \mathrm{C}\right)$ aerobically on a rotatory shaker for 14 days.

The mycelia mats produced were harvested by filtering the cultures through preweighed Whatman filter paper (No 1). The filter paper bearing the mycelial mats were dried in an oven at $70^{\circ} \mathrm{C}$ for 48hours and re weighed. The yield of dry mycelia biomass was obtained by subtracting the weight of the filter paper alone from the weight of the filter paper and the mycelia biomass (Bennet et al., 1997).

\section{RESULTS AND DISCUSSION}

The responses of the test isolates were found to vary when grown at the same concentrations of the test metals. At $5 \mu \mathrm{g} / \mathrm{ml}$, A.niger, A. fumigatus, Penicillium sp., Fusarium sp. and A. flavus were the most resistant to $\mathrm{Pb}$. Similar response was also noted for the same level of concentration of $\mathrm{Ni}$ (Figure 1). However, Cd was found to suppress the growth of all isolates except Penicillium sp. and A. carbonarius at $5 \mu \mathrm{g} / \mathrm{ml}$ concentration.

Increasing the concentration of the test metals to $10 \mu \mathrm{g} / \mathrm{ml}$ yielded same trend of resistance among the isolates to $\mathrm{Pb}, \mathrm{Ni}$ and $\mathrm{Cd}$ (Figure 2). However the mean yield of dry biomass was generally lower at $10 \mu \mathrm{g} / \mathrm{ml}$ than at $5 \mu \mathrm{g} / \mathrm{ml}$. 
However, increasing the levels of the test metals to $15 \mu \mathrm{g} / \mathrm{ml}$ resulted in significant reduction in the biomass yield of all the isolates tested (Figure 3). Ni appeared to be better resisted at this concentration compared to $\mathrm{Pb}$ and $\mathrm{Cd}$.

The analysis of the data revealed that, genera and species of fungi vary in their capacity to resist $\mathrm{Pb}, \mathrm{Ni}$ and Cd. For instance, A. fumigatus, A. carbonarius and $A$. niger appeared to be the most resistance to $\mathrm{Pb}$ followed by Penicillium sp and Fusarium sp. But of A. flavus, Curvularia sp. and Nigrospora sp. was suppressed by the same metal on the other hand, $A$. niger, A. carbonarius and Fusarium sp. were found to be the most resistant to $\mathrm{Ni}$ while $\mathrm{Cd}$ suppressed the growth of all tested isolates except Penicillium sp. and $A$. carbonarius.

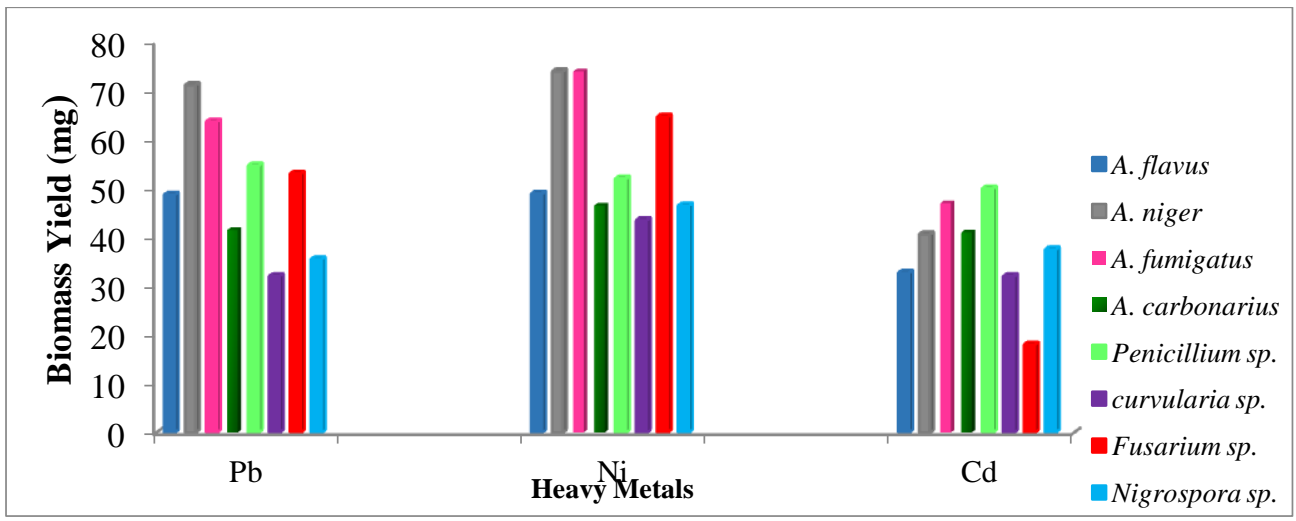

Fig 1: Mean Biomass Yield of Fungal Isolates to $5 \mu \mathrm{g} / \mathrm{ml}$ of Heavy Metals

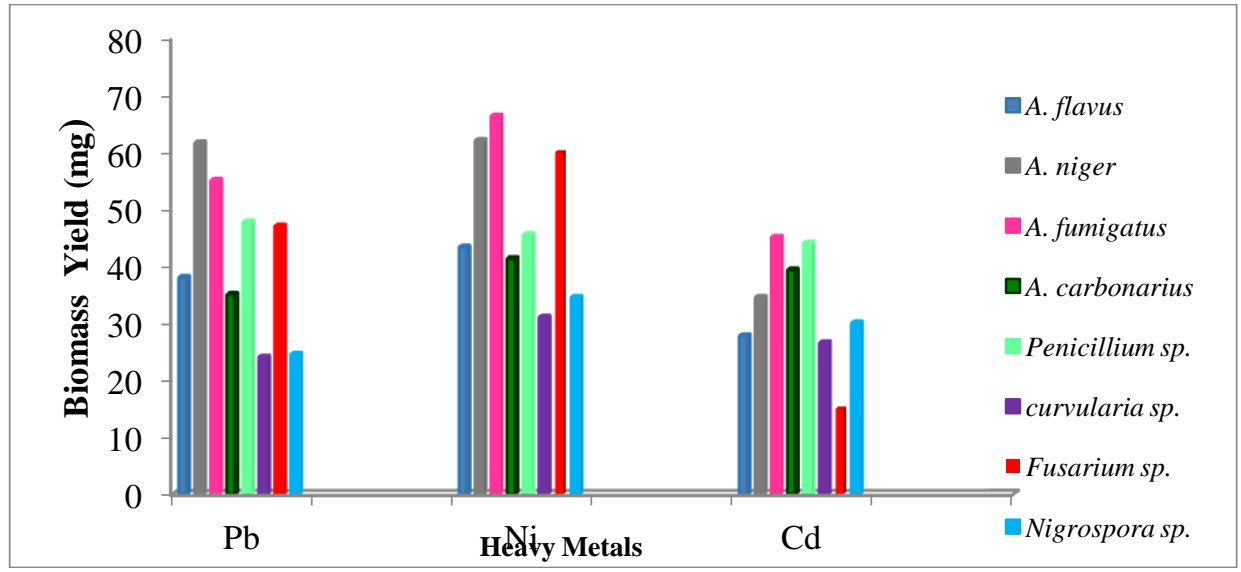

Fig 2: Mean Biomass Yield of Fungal Isolates to $10 \mu \mathrm{g} / \mathrm{ml}$ of Heavy Metals

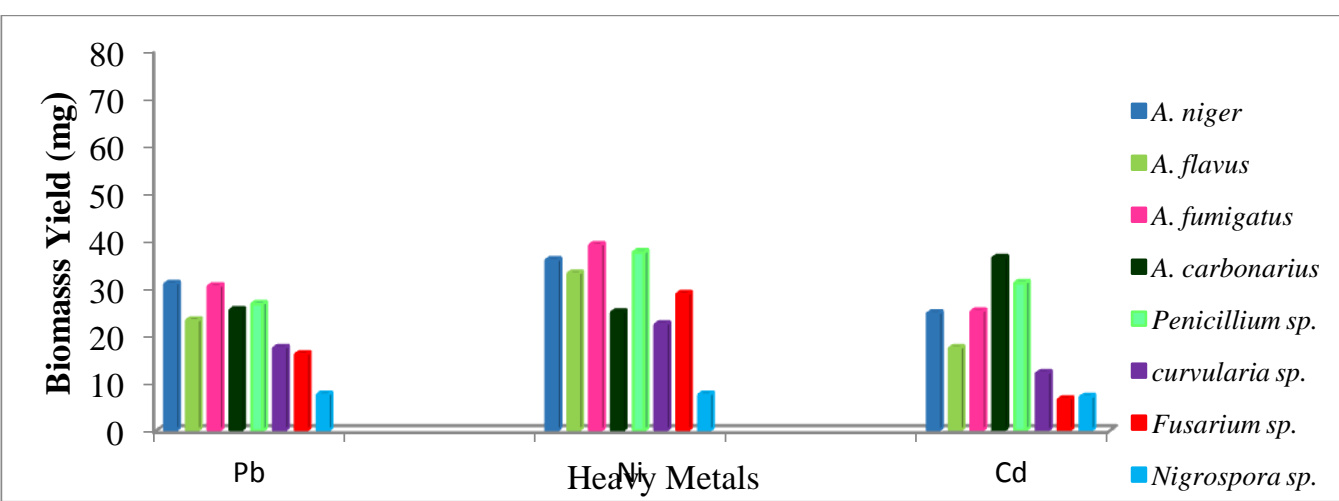

Fig 3: Mean Biomass Yield of Fungal Isolates to $15 \mu \mathrm{g} / \mathrm{ml}$ of Heavy Metals

${ }^{*}$ EZEONUEGBU, B.A.; MACHIDO, D.A.; YAKUBU, S.E. 
The wide spread resistance to $\mathrm{Pb}, \mathrm{Ni}$ and $\mathrm{Cd}$ observed among fungal residents of refinery effluents and effluent impacted river agree with the observations made by Ulfig et al. (2003). According to these authors, fungal communities survive and grow under strong heavy metal contaminated water and still play important role in the maintenance of ecological conditions in water bodies.

To survive and grow at the tested concentrations of $\mathrm{Pb}, \mathrm{Ni}$ and $\mathrm{Cd}$, the test isolates ought to have developed mechanisms by which the toxicity of the metals is circumvented. Several of such mechanisms have been reported to be employed by fungi growing in environments containing elevated levels of heavy metals. These includes; metal exclusion by permeable barriers (Nies and Silver, 1995), extracellular sequestration or biosorption (Nilanjana et al., 2008) and enzymatic modification of the metal ions to less toxic form (Rosen, 2002; Keong 2003). In addition, fungi are reported to possess specific genes for resistance to heavy metal ions. Mostly, these genes are chromosomal but others are acquired through plasmids (Nies, 1999) and the plasmid encoded genes are reported to be induced by the presence of specific metal ions (Rosen, 2002). The genes encoding the synthesis of metal binding proteins such as metallothionein are a good example (Valavanidis and Vlachioganni, 2010). These form the basis of bioaccumulation as a mechanism of resistance to heavy metal ions among fungi.

The variation in resistance to $\mathrm{Pb}, \mathrm{Ni}$ and $\mathrm{Cd}$ observed among genera and or species of fungi tested in this study suggest that, members of the same fungal community have different sensitivity to different metals (Keong 2003). As has been noted in this study, the same fungi could exhibit different response to different concentration of the same metal (Figures 1-3). Similar observations have been reported by Nies and Silver (1995).

The observations made in this study strongly suggest that, most of the isolates tested have the potentials as candidates in mycoremediation of refinery wastes. According to these authors, microbes that exhibit high resistance to high concentrations of soluble heavy metal ions would be selected for use for the treatment of heavy metal contaminated environments.

Conclusions: Based on the observations made in this study, the following conclusions have been drawn. Most fungi belonging to the genera Aspergillus spp., Penicillium spp., Curvularia spp., Fusarium spp. and Nigrospora spp. resident in refinery effluent impacted sites have high level of resistance to $\mathrm{Pb}, \mathrm{Ni}$ and $\mathrm{Cd}$.

Members of the genera Aspergillus spp., Penicillium spp., Fusarium spp. and Nigrospora spp. are the most resistant to $\mathrm{Pb}$ and $\mathrm{Ni}$.

Cd was least resisted by the same genera of fungi at 5,10 and $15 \mu \mathrm{g} / \mathrm{ml}$ concentration.

The isolates tested, could be employed in the treatment of refinery effluents and bioremediation of water bodies polluted with $\mathrm{Pb}, \mathrm{Ni}$ and $\mathrm{Cd}$.

\section{REFERENCES}

Ashok, K., Balwant, S.B. and Vishnu D.J. (2010). Biosorption of Heavy Metals by four acclimated microbial species, Bacillus spp., Pseudomonas spp., Staphylococcus spp. and Aspergillus niger. Journal of Biology and Environmental Science, 4(12), 97-108.

Ayenimo, J. G., Adeeyinwo, C. E. and Amoo, I. A. (2005). Heavy metal pollutants in warri river, Nigeria. Kragujevac Journal of Science. 27:4350 .

Bako, S.P., Chukwunonso, D. and Adamu, A.K. (2002). Bio-remediation of refinery effluents by strains of Pseudomonas aerugenosa and Penicillium janthinellum. Applied Ecology and Environmental Research, 6(3): 49-60.

Barrat, S.R., Ennos, A.R., Greenhalgh, M., Robinson, G.D. and Hadley, P.S (2003). Fungi are the predominant microorganisms responsible for degradation of soil buried with polyester polyurethane over a range of soil water holding capacities. Journal of Applied Microbiology, 95: 78-85.

Bennet, J.W., Wunch, K.G. and Faison, B.D. (2002). Use of fungi in biodegradation: of fungi in bioremediation. In: Manual of Environmental Microbiology Washington D.C.: ASM Press. pp. $960-971$.

Cerniglia, C.E. (1992). Biodegradation of polycyclic aromatic hydrocarbons. Biodegradation, 3, 351368

David, L. and Jay, D.K. (2009). Developing Aspergillus as a host for heterologous expression. Biotechnology Advances, 27: 53-75. 
Dugal, S. and Gangawane, M. (2012). Metal tolerance and potential of penicillium species for use in mycoremediation.

Emoyan, O.O., Ogban, F.E, and Akarah, E. (2006). Evaluation of Heavy Metals Loading of River Ijana in Ekpan - Warri, Nigeria. Journal of Applied Science and Environmental Management. 10 (2) 121 - 127.

Hakeem, A.S, and Bhatnagar,B. (2010). Heavy metal reduction of pulp and paper mill effluent by indigenous microbes. Asian Jornal of Experimental Biological Science, 1:203.

Kari, T.K, Annele, H., and Martin, H. (2003). Degradation of Benzopyrene by literdecomposing basiodiomycete Stropharia coronilla: Role of manganese peroxidase. Applied and Environmental Microbiology, 69(7): 3957-3964.

Keong, T.W. (2003). Bioleaching of Heavy Metals from Electronic Scrap Material (Esm) by Aspergillus niger and Penicillium simplicissimum. Unpublished MSc Thesis. National University of Singapore.

Klich, M.A. (2002). Identification of Common Aspergillus species. Centraal Bureau Voor Schimmel Culture, Utrecht, Netherland.

Martin, U., Zuzana, K., Jaroslav, S., Slavomír, C., Milan, K., Jan, M., Pavol, L., Marek, K. and Katarina, G. (2010). Biosorption and Bioaccumulation of Thallium (I) and Its Effect on Growth of Neosartorya fischeri Strain. Polish Journal of Environmental Studies, 19(2): 457460.

Nies, D. and Silver, S. (1995) Ion efflux systems involved in bacterial metal resistances. Journal of Indian Microbiology 14: 186-199.

Nies, D.H. (1999). Microbial heavy metal resistance. Applied Microbiology and Biotechnology, 51: 730-750.

Nilanjana, D., Vimla, R. and Karthika, K. (2008). Biosorption of Heavy Metal- An Overview. Indian Journal of Biotechnology, 7: 159-169.
Rosen, B.P. (2002). Transport and detoxification systems for transition metals, heavy metals and metalloids in eukaryotic and prokaryotic microbes. Components of Biochemistry and Physiology A Molecular Integrated Physiology, 133: 689-93.

Shankar, C., Sridevi, D., Joonhong, P., Dexilin, M., Thamaraiselvi, K. (2007). Biosorption of chromium and nickel by heavy metal resistant fungal and bacterial isolates. Journal of Hazardous Materials, 146: 270-277.

Thipeswamy, B., Shivakumar, C.K. and Krishnapa, M. (2012). Bioaccumulation potentials of Aspergillusniger and Aspergillusflavus for heavy metal removal from paper mill effluent. Journal of Environmental Biology, 33:1063-1068.

Ulfig, K., Płaza, G., Worsztynowicz, A., Mańko, T., Tienz, A.J. and Brigmon, R. L. (2003). Keratinolytic Fungi as Indicators of Hydrocarbon Contamination and Bioremediation Progress in a Petroleum Refinery. Polish Journal of Environmental Studies 12(2): 245-250.

Urooj, Z., Ashley, H. and Geoffrey, D.R. (2013). Fungal communities associated with biodegradation of polyester polyurethane buried under compost at different temperature. Applied and Environmental Microbiology, 79(23): 73137324.

Valavanidis, A. and Vlachogianni, T. (2010). Metal Pollution in Ecosystems. Ecotoxicology Studies and Risk Assessment in the Marine Environment. Science advances on Environment, Toxicology \& Ecotoxicology issuesnwww.chemtox-ecotox. valavanidis@chem.uoa.gr and thvlach@chem.uoa.gr.

VanHamme, J.D., Singh, A. and Ward, O.P. (2003): Recent Advances in Petroleum Microbiology. Molecular Biology Review, 67 (4): 503-549.

Wuyep, P.A., Chuma, A. G., Awodi, S. and Nok, A.J. (2007). Biosorption of $\mathrm{Cr}, \mathrm{Mn}, \mathrm{Fe}, \mathrm{Ni}, \mathrm{Cu}$ and $\mathrm{Pb}$ metals from petroleum refinery effluent by calcium alginate immobilized mycelia of Polyporus squamosus. Scientific Research and Essay, 7: 217-22. 